\title{
KRATKE NOVELE - NEDOVRŠENA III. KNJIGA NOVELA VLADANA DESNICE I DRUGI NOVELISTIČKI TEKSTOVI IZ PIŠČEVE OSTAVŠTINE
}

\section{Vladan Bajčeta}

UDK: 821.163.42-32Desnica, V.(049.3)

Izvorni znanstveni članak

Sažetak: U pogledu umjetničkih tekstova, rukopisna ostavština Vladana Desnice najbogatija je piščevim novelističkim radovima. Trideset i sedam rukopisa i daktilograma različitog obima i stepena dovršenosti, od kojih je samo jedan publikovan u periodici, otvaraju vrata u Desničinu pripovijedačku radionicu i bitno mijenjaju sliku o tom segmentu njegovog književnog rada. Na osnovu sačuvanog spiska koji čini osamnaest naslova, jasno je da je Desnica u planu imao III. knjigu novela ili Kratkih novela, kako su glasili potencijalni naslovi zamišljene publikacije. Očito odustajući od prvobitne namjere, vidno je da je Desnica radio na svojim pripovijetkama sa planom da ih u nekoj drugoj koncepcijskoj formi objavi. U radu su predočena tekstološka razmatranja čitavog korpusa ovih Desničinih tekstova, zatim njihovo sagledavanje u kontekstu piščevog novelističkog opusa i na kraju pregledna analiza pojedinih aspekata njihove imanentne poetike koji unose izvjesna pomjeranja u razumijevanju Desničinog pripovijedačkog postupka.

Ključne riječi: pripovijetka, novela, kratka novela, rukopis, ostavština

I.

7] književnoj ostavštini Vladana Desnice između drugih značajnih dokumenata pronađen je nemali broj piščevih pripovijednih tekstova. Riječ je o četiri fascikle, obilježene kao „Novele u radu“, sa trideset i sedam pripovijedaka na različitom stepenu umjetničke dovršenosti: od skica, koncepata i prvih rukopisnih varijanti, zatim fragmentarnih mašinopisa, do temeljno redigovanih verzija, odnosno čistopisa pojedinih novela. Već sâm broj zatečenih naslova prevazilazi Desničin kanonski novelistički opus od trideset i dvije pripovijetke objavljene u četiri zbirke ${ }^{1}$, a umjetnička uspjelost pojedinih među njima ne-

$1 \quad$ Vladan Desnica, Olupine na suncu, Zagreb 1952.; Isti, Proljeće u Badrovcu, Beograd 1955.; Isti, Tu, odmah pored nas, Novi Sad 1956.; Isti, Fratar sa zelenom bradom, Zagreb 1959. 
sumnjivo doprinosi novom sagledavanju i potpunijem razumijevanju tog unekoliko marginalizovanog dijela piščevog literarnog rada.

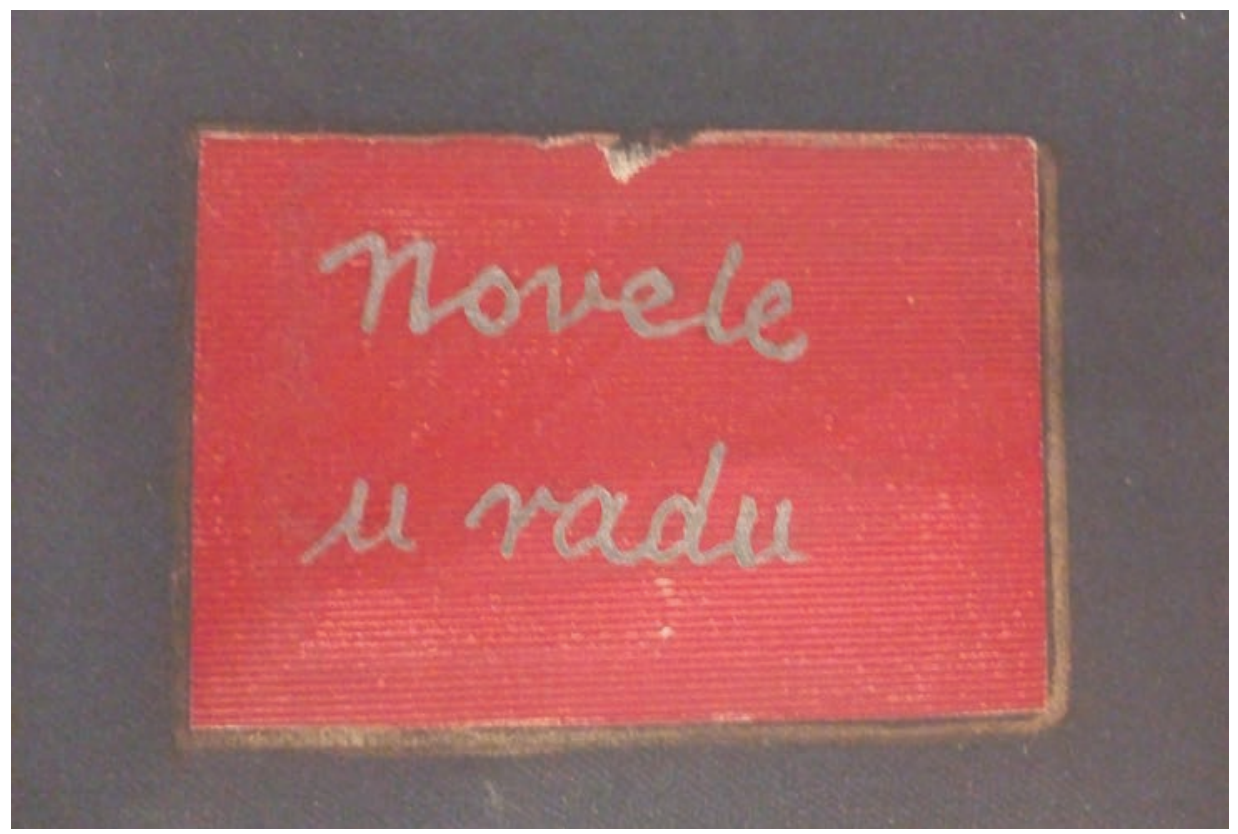

Sl. 1. „Novele u radu“

Osnovna nedoumica koja se priređivaču u ovakvim prilikama prije svih drugih nameće odnosi se na kriterijume pri izboru tekstova za buduće kritičko izdanje. Dobronamjerno kolegijalno upozorenje profesora Dušana Marinkovića, predanog istraživača Desničinih rukopisa i priređivača piščevog dvotomnog Hotimičnog iskustva ${ }^{2}$, koje opominje „da svako onaj koji će se prihvatiti objavljivanja takvih tekstova mora vrlo dobro da raščisti i jasno se pozicionira na sam stav Vladana Desnice u odnosu na autorske zaostavštine “3, korisno je podsjećanje na neželjenu mogućnost da se piscu na ovaj način ne učini, upravo prema njegovim vlastitim riječima, „medvjeđa usluga“ “ ${ }^{4}$ Stoga je izbor ovog puta samo na onim tekstovima koji predstavljaju očigledno dovršene umjetničke cjeline, odnosno na onim koji i u svojoj relativnoj nedovršenosti posjeduju izvjesnu smisaonu cjelovitost. Drugi slučaj pretežno se odnosi na pripovijetke dominantno refleksivnog karaktera, koje lakše izdržavaju probu postavljenih kriterijuma. Iako u jednom broju fragmentarni, značajan dio i takvih Desničinih tekstova reprezentativni su uzorci njegovog proznog stvaralaštva: to su stranice u dubokom saglasju sa onim vidom i dometom umjetničkog izraza koji je Desnica

2 Isti, Hotimično iskustvo I i II (prir. Dušan Marinković), Zagreb 2005. - 2006.

3 Dušan Marinković, „Nove spoznaje o Vladanu Desnici“, Desničini susreti 2005.-2008. Zbornik radova (ur. Drago Roksandić i Ivana Cvijović Javorina), Zagreb 2010., 251.

4 Dr. sc. Uroš Desnica svjedoči o razmišljanjima svog oca povodom naznačenog pitanja: „Znatan dio ostavštine je Vladan spalio (peć u sobi danima je gorila na tim papirima!). Sjećamo se da je znao govoriti: 'Često se napravi autoru medvjeđu uslugu kad se posmrtno objave nedovršene stvari’ (ili slično na tu temu). Zato smo mi i bili odlučili čekati oko/preko 50 godina dok se išta 'novog' njegovog objavi, a i na to smo se ipak nekako odlučili misleći, otprilike: kako je puno toga spalio, da je htio, bio bi spalio i ovo što je preostalo - nije da nije imao vremena..." (Lična prepiska). 
ostvario u svom najznačajnijem djelu - romanu Proljeća Ivana Galeba. Meditativnost, kao i dijaloška refleksivnost jednog broja ovih pripovijedaka, ispoljenje su iste strane piščeve stvaralačke prirode.

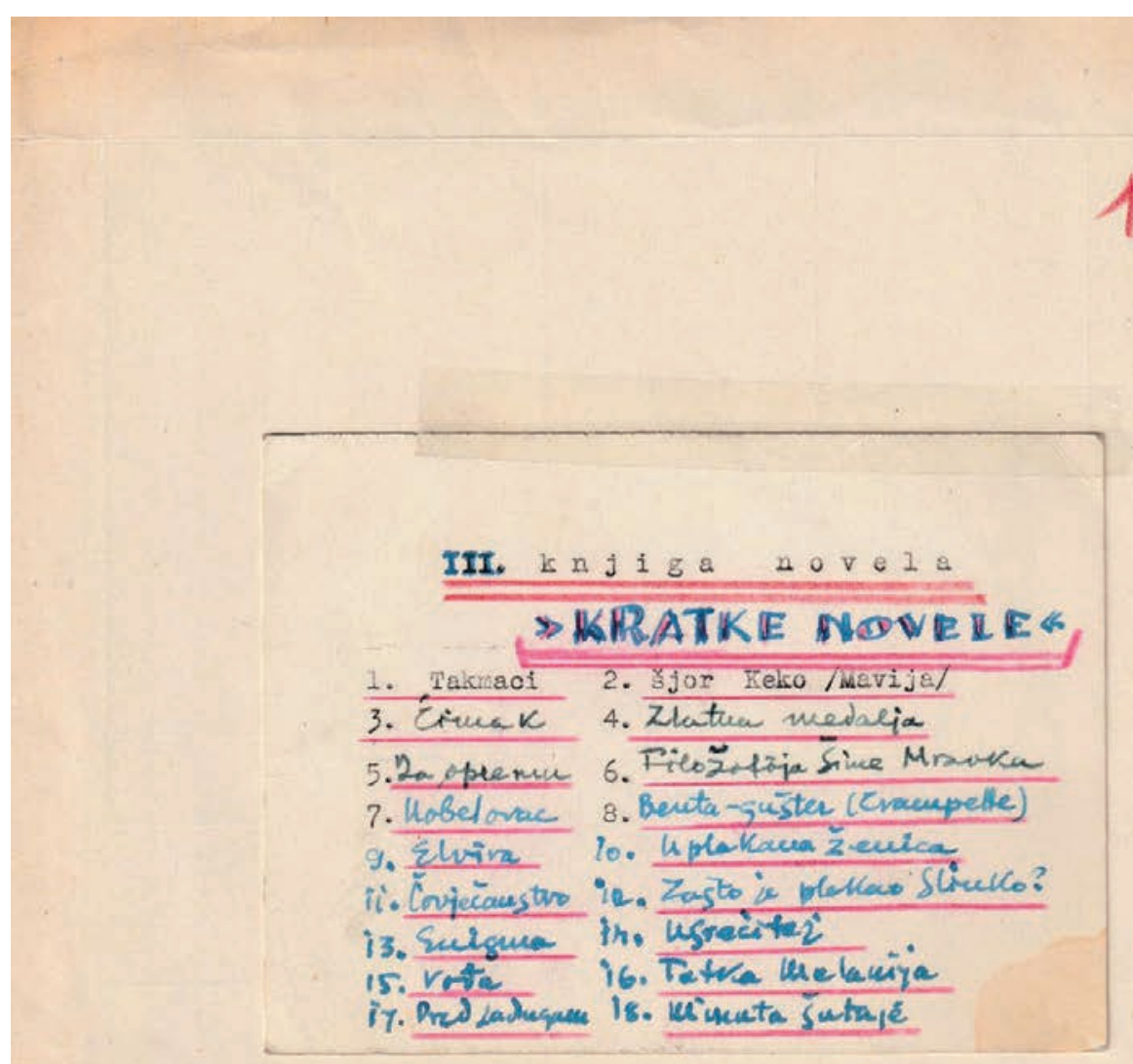


$\mathrm{Na}$ osnovu autorskog spiska pronađenog među rukopisima jasno se vidi da je Desnica, pored Olupina na suncu i knjige Tu, odmah pored nas, u planu imao i treću originalnu zbirku priča, odnosno Kratkih novela, kako je naslovio svojeručno sačinjen popis. Od tog plana Desnica je očigledno odustao, budući da su neke od pripovijedaka sa spiska pronašle svoje mjesto u njegovim autorizovanim djelima. Stoga se kao priređivačev zadatak logično nametnula rekonstrukcija pojedinačnih tekstova, umjesto rekonstrukcije knjige po evidentno napuštenom ranijem konceptu. Ipak, radni sadržaj III. knjige novela, kome je pridodat jednako neutralni ali po svemu sudeći adekvatan naslov Kratke novele, može poslužiti za određene pretpostavke o nekim Desničinim zamislima u vezi sa njegovom neobjavljenom zbirkom priča:

1. Takmaci

2. Šjor Keko (Mavija)

3. Čirak

4. Zlatna medalja

5. Za opremu

6. Filozofija Šime Mravka

7. Nobelovac

8. Benta-guster (Crampette)

9. Elvira

10. Uplakana ženica

11. Covječanstvo

12. Zašto je plakao Slinko

13. Enigma

14. Usrećitelj

15. Voda

16. Tetka Melanija

17. Pred zadrugom

18. Minuta šutnje.

Osim naslova koji čitaocu već mogu biti poznati, a to su Benta-gušter i Zašto je plakao Slinko, objavljeni u zbirci Tu, odmah pored nas - drugi i kao jedno poglavlje Proljećâ Ivana

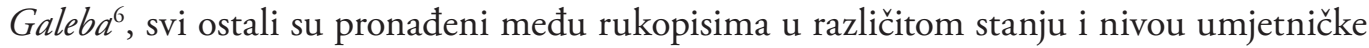
dovršenosti. Priče Takmaci, Šjor Keko, Čirak, Zlatna medalja, Za opremu, Filozofija Šime Mravka, Elvira, Usrecitelj, Voda, Pred zadrugom i Minuta šutnje (preimenovana u Pet minuta) zastale su na nivou nacrta, odnosno fragmenata započetih proznih radova. ${ }^{7}$ Naslovi

5 V. Desnica, Tu, odmah pored nas, 47-52, 96-108. Odlomak prve priče objavljen je ranije u periodici: „Benta-gušter“ (iz „Solilokvija gospodina Pinka“), Letopis Matice srpske, 131/1955., knj. 376, br. 7-8, 37-45.

6 V. Desnica, Proljeća Ivana Galeba, Beograd 1990., 129-132.

7 Još dva naslova: Pop Mile i Samoubistvo u provinciji, koji se ne nalaze u sadržaju Kratkih novela, u tekstološkom pogledu pripadaju istoj kategoriji. 
Nobelovac ${ }^{8}$, Uplakana ženica, Čovječanstvo ${ }^{9}$, Tetka Melanija, Aperitiv, Dva prijatelja, Istina o Adalbertu, Noć u Skrocima, Onkel, Posjeta pjesniku, Svejednako i Zasluženi odmor predstavljaju kratke priče pisane u Desničinom prepoznatljivom narativnom maniru, koje istovremeno otkrivaju i neke nove postupke piščevih pripovijedačkih strategija.

2.

Cjelokupni novelistički opus Vladana Desnice svrsishodnije je sagledavati tipološki, prije nego po fazama, upravo onako kako je to sâm pisac sugerisao u napomeni uz knjigu $T u$, odmah pored nas. Desnica govori o dva „kruga“ koji razdvajaju njegova pripovijedačka interesovanja:

I u ovoj zbirci, kao i u Olupinama na suncu, pojavljuju se uporedo, izmiješane i neodijeljene, proze koje zapravo potiču iz dva različita kruga i koje, idealno, sačinjavaju dvije posebne knjige: one iz još nezavršenog ciklusa pretežno regionalnog vida (ili bar privida), i one druge, općenitijeg, sasvim neregionalnog karaktera. ${ }^{10}$

Prvoj grupi pripadale bi pripovijetke kao što su Oko, Florjanović, ili Proljeće u Badrovcu, a drugoj Pravda, Delta, ili Priča of fratru sa zelenom bradom. Prve karakteriše vezanost za regionalnu topografiju, a zatim, tradicionalniji narativni prosede koji baštini realističko, odnosno modernističko nasleđe evropske i srpske književnosti. Druge su po pravilu kratke priče, u kojima pisac umjetnički propituje određena filozofska, etička, psihološka, juridička i druga pitanja posredstvom svedenijih sižea i sa većim udjelom narativne refleksije. Dvanaest naslova iz ostavštine izabranih za publikovanje pripadaju u najvećoj mjeri prozama „općenitijeg karaktera“, nerijetko i u onim primjerima koji asociraju na piščeve radove „regionalnog (pri)vida“.

Od pripovijedaka koje možemo smatrati dovršenim ili u značajnoj mjeri zaokruženim, njih pet predviđeno je za III. knjigu novela: Svejednako (Filozofija Šime Mravka), Nobelovac, Uplakana ženica, Čovječanstvo i Tetka Melanija. Ostalih šest: Aperitiv, Dva prijatelja, Istina o Adalbertu, Noć u Skrocima, Onkel, Posjeta pjesniku i Zasluženi odmor nije uvršteno u postojeći koncept. Razlog da se ove pripovijetke nađu objavljene u jednoj knjizi proizlazi iz njihove tipološke srodnosti, kako je, već i prema navedenom piščevom viđenju, najadekvatnije posmatrati taj segment njegovog književnog rada. Takav pristup u izvjesnoj mjeri određuje druga nužnost, a to je činjenica da se vrlo malom broju ovih tekstova može pouzdano odrediti vrijeme nastanka. Budući da je Desnica izuzetno dugo radio na svim svojim

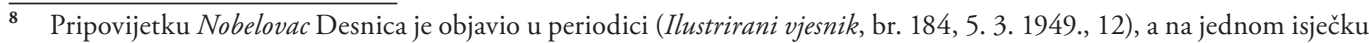
iz tog časopisa piščevom rukom je uneseno nekoliko stilskih i strukturnih izmjena, nesumnjivo sa namjerom da se tekst razmotri za objavljivanje u nekoj narednoj prilici. Prekucani primjerak sa datumom prvog publikovanja Bidne šinjorine (Novela film, 6/1954., br. 38, 13), kasnija Dva pretendenta iz zbirke Tu, odmah pored nas, takođe se nalazi među pronađenim pripovijetkama.

9 Odlomak iz pripovijetke Covječanstvo objavljen je posthumno, na petu godišnjicu piščeve smrti: Letopis Matice srpske, 131/1955., knj. 376, br. 7-8, 429-432.

10 V. Desnica, Tu, odmah pored nas, 201. 
tekstovima, priređivač se neprestano nalazi pred neprilikom da donosi zaključke o njihovoj pripadnosti određenoj „fazi“ piščevog književnog stvaralaštva. Ipak, treba imati na umu da je Desničin kasni ulazak u književnost, u smislu piščeve društvene promocije, obilježen objektivnim okolnostima, koje umnogome određuju i njegovu književnoistorijsku poziciju. Naime, Desničino mjesto u poetičkom preobražaju posleratne srpske i jugoslovenske književnosti zahtjeva temeljno prevrednovanje kada je o pripovijeci riječ, s obzirom na to da je nemali broj njegovih književnih radova nastao bitno ranije u odnosu na trenutak njihovog objavljivanja. Desnica je već 30-ih i 40-ih godina pisao prozu koja je u kontekstu 50-ih godina dvadesetog vijeka književnoistorijski prihvaćena kao dio šireg talasa u nastojanjima ka prevladavanju poetike socijalističkog realizma. Otuda, Desnica je uskraćen za mjesto nedvosmislenog preteče takvih umjetničkih težnji, a naročito u svojim pripovijetkama, iz razloga što je tokom rata izgubio čitavu zbirku poslatu izdavaču Geci Konu ${ }^{11}$, kao i znatan broj drugih tekstova na svom putovanju iz Zadra u Split 1942. godine. ${ }^{12}$ Riječju, Desničine poetičke inovacije dolazile su u trenutku kada više nisu mogle biti upadljive na način kako bi bilo da su njegove pripovijetke objavljene neposredno nakon samog njihovog nastanka.

U vezi sa datiranjem ovih tekstova ipak je moguće ponuditi nekoliko okvirnih pretpostavki. Osvrćući se na svoje književne početke u jednom intervjuu za Politiku, Desnica će priču Zasluženi odmor pomenuti kao svoj rani novelistički pokušaj:

Ako ipak pokušam da nekako odredim koji je moj prvi rad pisan s namjerom da ga objavim, to je slučajno u nekoj vezi baš sa „Politikom“: dugo sam se mučio sa novelom od petšest kartica koju sam bio namijenio „Politikinom“ podlisku „Priča politike“. Naslov joj je bio Zasluženi odmor. Tema je bila sasvim dobra za valjanu priču, a ispala mi je pomalo nevješta ali sasvim živa. Napisao sam bezbroj varijanti. (...) Nisam je nikad objavio. ${ }^{13}$

U ostavštini su pronađene dvije od „bezbroj varijanti“ te pripovijetke i već na osnovu površnog uvida (obim teksta, rukopisne ispravke) nije teško zaključiti koja u piščevoj namjeri predstavlja dovršeniju formu. Za ovu priliku važnije je: piščeva evokacija upućuje na to koji se od svih pronađenih naslova eventualno može smatrati najstarijim. Budući da

$\overline{11}$ Bilježeći u jednom svom, u trećem licu pisanom curriculumu vitae iz 1949. godine tu nezgodu, Desnica je vlastitu naklonjenost književnoj vrsti novele izdvojio kao prevashodnu: „Književnošću se bavi od ranih dana, ali je vrlo malo objavljivao. Kratko vrijeme pred rat poslao je Geci Konu jednu knjigu lirike koja je trebala da bude štampana, a imao je gotovu jednu knjigu novela; obje knjige, uz mnoge druge materijale, propale su mu u toku rata. Za vrijeme okupacije nije objavljivao ništa. Misli da mu od književnih vrsta najviše odgovara novela, eventualno roman, a piše i liriku i pokoji članak i esej.“ Drago RoKsandić, „'Kud koje žure brzi kraci / a vode svi u bespuće'“: Vladan Desnica u Splitu od 1935. do 1941. godine", Split i Vladan Desnica 1918. - 1945.: Umjetničko stvaralaštvo izmecu kulture i politike. Zbornik radova sa znanstvenog skupa Desničini susreti 2015. (ur. Drago Roksandić i Ivana Cvijović Javorina), Zagreb 2016., 416.

12 U jednom intervjuu, Desnica je kasnije, sa sebi svojstvenim humorom, pričao o tom za njega svakako nemilom događaju: „Kada sam selio familiju iz Splita na selo, 1942. godine, iz predostrožnosti sam svojevremeno nosio pun kufer rukopisa. Grupa Talijana, nekakvih prodavača, galamdžija iz južne Italije, pokupila je i iskrcala u Šibeniku i moj kufer među svojim silnim prtljagom, kuferima i boščama. Dao sam oglas u novine da zadrže kufer i sitnice, a rukopise vrate uz obećanje obilate nagrade. 'Pošteni nalazač', naravno, ni ovog puta nije se našao. Sad razumijem njegovo ogorčenje kad je mjesto kakavih vrednota našao hrpu naškrabanih kartušina i to - na nepoznatom jeziku. Ta molim vas, ko bi još vraćao te kartušine vlasniku koji nam je priredio takvo razočarenje? Zamišljam kako je moj crnoputi, južnjački neznanac zabijelio očima ka nebu i progunđao 'Porca Madona'!“Jovan Radulović (prir.), Djelo nastaje dalje od pisaćeg stola, Beograd 2005., 87-88. (NIN (Beograd), 23. 6. 1961.) 
je Desnica svoj pripovijedački prvijenac već štampao u drugom broju Magazina Sjeverne Dalmacije za 1935. godinu, ${ }^{14}$ na osnovu navedene izjave noveli Zasluženi odmor ta godina može biti određena kao terminus post qua non. Po svoj prilici, ona je napisana, ili barem osmišljena i u velikoj mjeri razrađena, već u prvoj polovini tridesetih godina - ne kasnije od 1935. Osim koncepta od dvije stranice za pripovijetku Elvira, koji u zaglavlju sadrži datum i mjesto nastanka „10. 9. 47. Zgb.“, jedina pouzdano datirana pripovijetka je Čovječanstvo - u dnu poslednje stranice mašinopisa stoji „19. IV. 1948“.15 Navedena godišta nešto govore: Desničine objavljene pripovijetke, sagledane u cjelini, mogle bi odati utisak da je pisac u prvom periodu svog rada (1952. - 1955. $)^{16}$ bio skloniji obimnijim pripovijednim formama kakve reprezentuju naslovi Od jutra do mraka, Bunarevac, ili Spiriti, a kasnije (1956. 1959. $)^{17}$ bliži kratkoj priči, kao što su Šarasta kutijica, Mudrac sa istoka, ili Delta. Međutim, upravo navedeni primjeri ukazuju na to da je Desnica od svojih početaka, pa do vremena neposredno prije nego što će se pojaviti sa svojim samostalnim književnim publikacijama, intenzivno i kroz više od dvije decenije njegovao formu „kratke novele“ ${ }^{18}$ Ta spisateljska sklonost očigledno ga nije napuštala ni u kasnijem periodu i predstavljala je jedno od najpostojanijih usmjerenja njegovog ukupnog literarnog rada. Prirodna i uobičajena pojava da se u ostavštini jednog pisca zateknu tekstovi na kojima je radio neposredno do pred smrt daje prostora vjerovanju da je neka od preostalih pripovijedaka pisana u šestoj deceniji dvadesetog vijeka, utoliko prije što se pojedine od njih ne nalaze u sadržaju III. knjige novela, koji je, sudeći prema nekoliko iz njega objavljenih priča, vjerovatno nastao znatno ranije.

\section{3.}

Istina o Adalbertu spada u grupu Desničinih novela koje umjetnički propituju relativnost zemaljske pravde. I sâm pravnik po obrazovanju, Desnica je u velikom broju književnih radova obrađivao motive pronađene u svom primarnom, činovničkom pozivu. Priča o službeniku oklevetanom da je ukrao nekoliko kašičica iz otmenog restorana i koji pokušava da pravnim putem stane u kraj toj difamaciji jezgrovito i efektno prikazuje nemoć institucija da pojedinca zaštiti od mehanizama glasine. Nabijeđujuću rečenicu: „Ovo je onaj što $j e \mathrm{u}$ restoranu ukrao žlicu“, sažetu u sentencu „Ovo je onaj od žlice“, nakon Adalbertove rehabilitacije smijenjuje novi trač: „Ovo je onaj koji nije ukrao žlicu“, skraćenu takođe u: „Ovo je onaj od žlice“ (kurziv - op. a.). Ogovaranju prirođena jezička ekonomija relativizovala je

14 V. Desnica, „Životna staza Jandrije Kutlače“, Magazin Sjeverne Dalmacije, 1935., 155-173.

15 Na jednoj rukom pisanoj bilješci za pripovijetku Takmaci stoji otkucan datum 22. VII. 1948., na drugoj 4. VIII. 1948. U sledećoj fazi pripovijetka dobija naziv Dva apendicitisa, pri čemu se prethodni naziv seli u zagradu, a datum bilježaka je: četvrtak, 5. V. 1949., 12,30 h. Pripovijetka nažalost nije umjetnički razvijena, a rijedak je slučaj, kao ovaj, preciznog datiranja po fazama rada na pripovijeci.

16 Olupine na suncu i Proljeće u Badrovcu.

17 Tu, odmah pored nas i Fratar sa zelenom bradom.

18 Pored pomenutih naslova, u ostavštini su pronađeni koncepti za još trinaest pripovijedaka: „Zugsführer" Parčina, Smrt, Imendan, Neodlučna, Guter Fritz / Hans, Crnogorac, Konvikt, Starci, Krokodil, Sijamske blizanke, Voda, Luca i Pijama. Riječ je pretežno o rukopisnim bilješkama, koje predstavljaju skice zamišljenih pripovijednih cjelina. 
svaki napor kompromitovanog da se odbrani nedobronamjernog opanjkavanja, a tom saznanju Desnica je dao čehovljevski svedenu i savršenu formu. Ne zadržavajući se nikada na nivou prve zavodljive ideje, pisac svoju priču produbljuje ne toliko upadljivom, pa utoliko umjetnički efektnijom crtom paranoje na portretu glavnog junaka, pravog razloga njegove nesreće, u načinu na koji „su se iz vlažnih haustora, iz sjene platina, iz kavanskih jazbina, iz drndavih tramvaja pružali za njim prsti“. Po tim odlikama Istina o Adalbertu uzoran je, reprezentativan tekst Desničinih kratkih novela.

Tetka Melanija je svojevrsna portret-priča, koja u najboljem svijetlu predstavlja Desnicu kao pisca izrazitog humorističkog potencijala. Živopisni lik samoproglašene matrone, nekritički uvjerene u vlastita mišljenja i sudove, patološki pedantne hipohondre, posesivne i škrte porodične upraviteljke, Desnica prikazuje sa rijetko balansiranim literarnim izrazom na granici humora i satire. Narativnom gradacijom òbiljēžja tetka-Melanijinog karaktera, pripovijetka domašuje komički vrhunac kada narator, podstaknut pjesmom Silvija Strahimira Kranjčevića Posljednji Adam, ${ }^{19}$ sanja Sudnji dan, koji kao zadnji trag čovječanstva $\mathrm{u}$ potopu odnosi tetkin altdeutsch ormar. $\mathrm{U}$ operetnom epilogu, pocrtanom aluzijom na Riharda Vagnera (Loengrinov labud), čime se ironijski suptilno zauzima tetka-Melanijina tačka gledišta, pripovijetka zaokružuje, u vidu implicitne autorefleksije, junakinjin domaštani život shvaćen iz vlastite perspektive kao sadržaj dostojan jednog uzvišenog libreta. Kako Desnica po svom običaju nije jednoznačan, ovu efektnu humoresku moguće je razumjeti i kao pritajenu satiričnu žaoku površnom feminizmu: Melanijin svijet je travestirani matrijarhat (govori se o tetka-Melaniji kao nosiocu vlasti, starešinstva) nastao iz njene proklamovane teze: „Kad se čovjek pokaže nesposoban da upravlja svojim poslovima, treba da žena uzme upravu u svoje ruke, i ja to potpuno odobravam“. Međutim, tetka-Melanijino upraviteljstvo posvećeno je isključivo stvarima neznatne važnosti, opsesivnoj i pretjeranoj obazrivosti prema pokućstvu i sitnijim predmetima, a opterećeno permanentnom brigom za vlastito zdravlje. Piščeve satiričke intencije delikatno su signalizirane ironijskim citatom Njegoša („učini ovo ili ono, udari desno ili lijevo, - svejednako te 'tragičeski konac prati'“) i uvođenjem u motivski korpus njegovog naslednika - knjaza Nikole - dvojice vladara zemljom u kojoj je srpski patrijarhalni obrazac dostigao svoju krajnju tačku. Uz još nekoliko naslova, Tetka Melanija potvrđuje Desnicu kao vrsnog književnog smjehotvorca, kakvim ga srećemo i u pripovijeci Nobelovac.

Satirički zaoštrena karikatura svjetski priznatog pisca, a ustvari, kako će se iz njegove proze u nastanku saznati, proizvođača šokantnih književnih trivijalnosti, usmjerena je ka pomodnom spisateljskom stavu „anganžovanog intelektualca“. Norbert Bruk je literarni opsenar koji komercijalizuje svoju slavu tako što putuje kontinentom i po zemljama centralnoevropske periferije igra ulogu duštveno-političkog mesije. Floskule savremenog proroka („Mira među narodima neće i ne može biti sve dotle, dokle svaki narod i svaki pojedinac ne provali vrata vlastitog egokratizma u kome je zarobljen") komični su pandan naslovima njegovih djela: Majmun sa srebrnim ogledalom, Trojica ili nijedan, Ključ bez rupice. I ovog

19 Pravi naslov Kranjčevićeve pjesme je Zadnji Adam. Silvije Strahimir Kranjčević, Izabrane pjesme, Beograd 1929., $51-55$. 


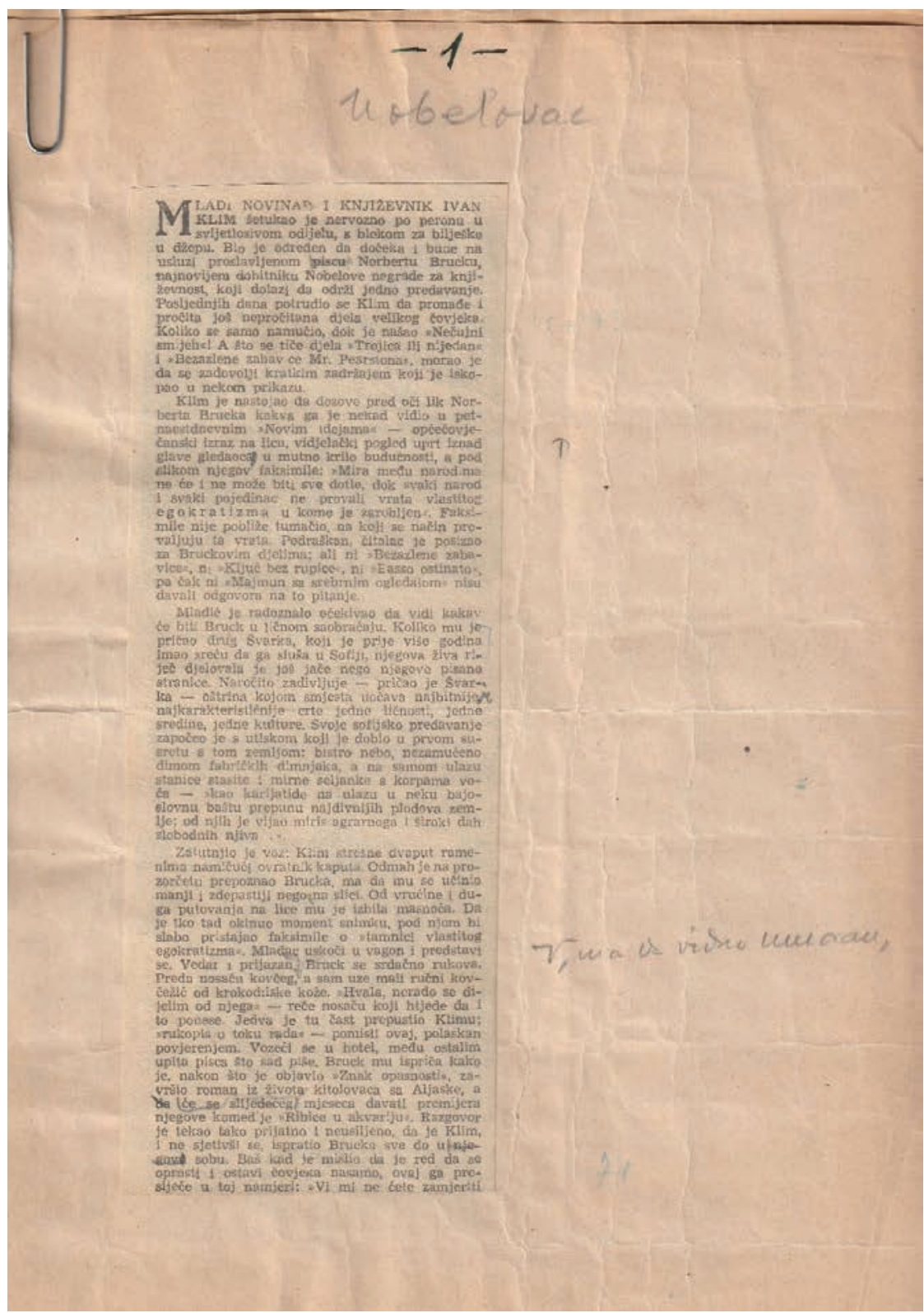

\section{Sl. 3. Nobelovac}

puta stepenujući karikaturalnost svog junaka, pisac, kao što je slučaj sa Tetka Melanijom, dolazi do patološkog egoizma kao suštine samozvanca. Bruk je čak doveden na samu ivicu groteske: opsesivno bavljenje sopstvenom fiziologijom više nije pretjerana briga za zdravlje, već kozmetičko prikrivanje nemara prema vlastitom organizmu. „Masno“, „gojazno“ tijelo, sa leđima posutim „krupnim izraslinama sličnim šturom kestenju“, potencirano je odbojna slika trivijalnog gurmana, koji svoje turneje mučno podnosi ne bi li gustirao nove nacionalne kuhinje, na šta će se skupa sa svojim konstantno ugroženim zdravljem u pismi- 
ma žaliti supruzi. Desnica je, prema svom prepoznatljivom običaju, drugom planu pripovijetke odredio dalekosežnije kritičko nastojanje. Naime, priča Nobelovac posjeduje moćan subverzivni kapacitet - ona uvjerljivo podriva zapadnoevropsku autopercepciju civilizacijske superiornosti u odnosu na eufemistički označen „egzotični“ Balkan. Brukov cinizam ispoljen u podsmijehu prema naporu „malih naroda“ da očuvaju svoju kulturnu baštinu, koji prikriva neiskrenom, sladunjavom i unaprijed pripremljenom poetizacijom svojih „prvih utisaka" u njihovim zemljama, Desnica podvrgava suverenom satiričkom razobličenju. Istovremeno (što doprinosi visokoj kvalitativnoj mjeri ove pripovijetke), Desnica implicitno ukazuje na jedini prihvatljiv način piščevog angažovanja, a to je angažovanje sredstvima sopstvene umjetnosti.

Drugačija vrsta „angažmana“, takvog koji bi mogao biti shvaćen kao ideološka jeres da je pripovijetka slučajno objavljena u nekoj od poslednjih dvadeset godina piščevog života, kada je po svoj prilici i nastala, prisutna je u priči Svejednako. To je svojevrstan refleksivni kroki nižeg državnog činovnika, koji promišlja o nastupu radikalnog zaokreta na političkoj sceni njegovog doba. Ne određujući konkretno istorijsko vrijeme, Desničina hotimična univerzalizacija nedvosmisleno cilja i na piščevu epohu, naročito centralnim simbolom priče - metonimijom vječitog smjenjivanja vlasti - portretom velikog vođe:

I za svakoga se govorilo da je to, najzad, onaj pravi, da je to najviši, izabrani sin naroda, da se poslije opet $\mathrm{i}$ to smijeni i da se opet to isto govori za slijednika i porekne, da se kaže da to nije bio onaj pravi, nego dapače sve protivno, sve najgore od toga, a da je tek novi onaj pravi pravcati, najizabraniji. I tako bez kraja i konca.

Neupitna aluzija na entuzijazam jugoslovenskog socijalizma (oličen u njegovom prepoznatljivom amblemu) koja iskazuje blasfemično nepovjerenje u trajnost utopije u nastajanju, otkriva jednog novog Desnicu. Ipak, njegov spisateljski osjećaj za pojedinosti koje izražavaju vodeću misao, osnovna ideja sadržana u katalogu efemernosti skromne egzistencije Franja Vukasice kazuje da je ubogo, nedostojno življenje to što u svijetu zaista pretrajava, a ne konačno dočekani „izabrani sin naroda“. Franjov kolega „Šutek sa prelomljenom i koncem prevezanom štangetom naočala“, peć „s kvakom lišenom porculanskog nazuvka“, rezanci „repe u prezapaprenoj čorbi“ - tipični su simboli Desničinog viđenja svekolike bijede „golog ljudskog postojanja“. Pripovijetka iskazuje Desničin poznati umjetnički paradoks o prolaznosti kao jedinoj trajnosti.

Čovječanstvo pripada onom tipu Desničinog proznog izraza naglašeno intelektualističke sadržine u formi filozofskog dijaloga: naracija je svedena na minimum, a tekst rèplikā predstavlja ili raspravu, ili esejistički razgranatu elaboraciju o opšteljudskim pitanjima poput bolesti, smrti, rata, umjetnosti i sl. To su literarizovani razgovori u književno-filozofskoj tradiciji od Platonovih dijaloga do romana F. M. Dostojevskog i Tomasa Mana. Ta vrsta Desničine literature najbolji primjer pronalazi u romanu Pronalazak Athanatika, ${ }^{20}$ a u nju spadaju i pripovijetke Dva prijatelja i Posjeta pjesniku. Njih odlikuje sučeljavanje opozitnih perspektiva - racionalne, naučne, sa jedne, i intuitivne, stvaralačke, sa druge strane. U pri- 


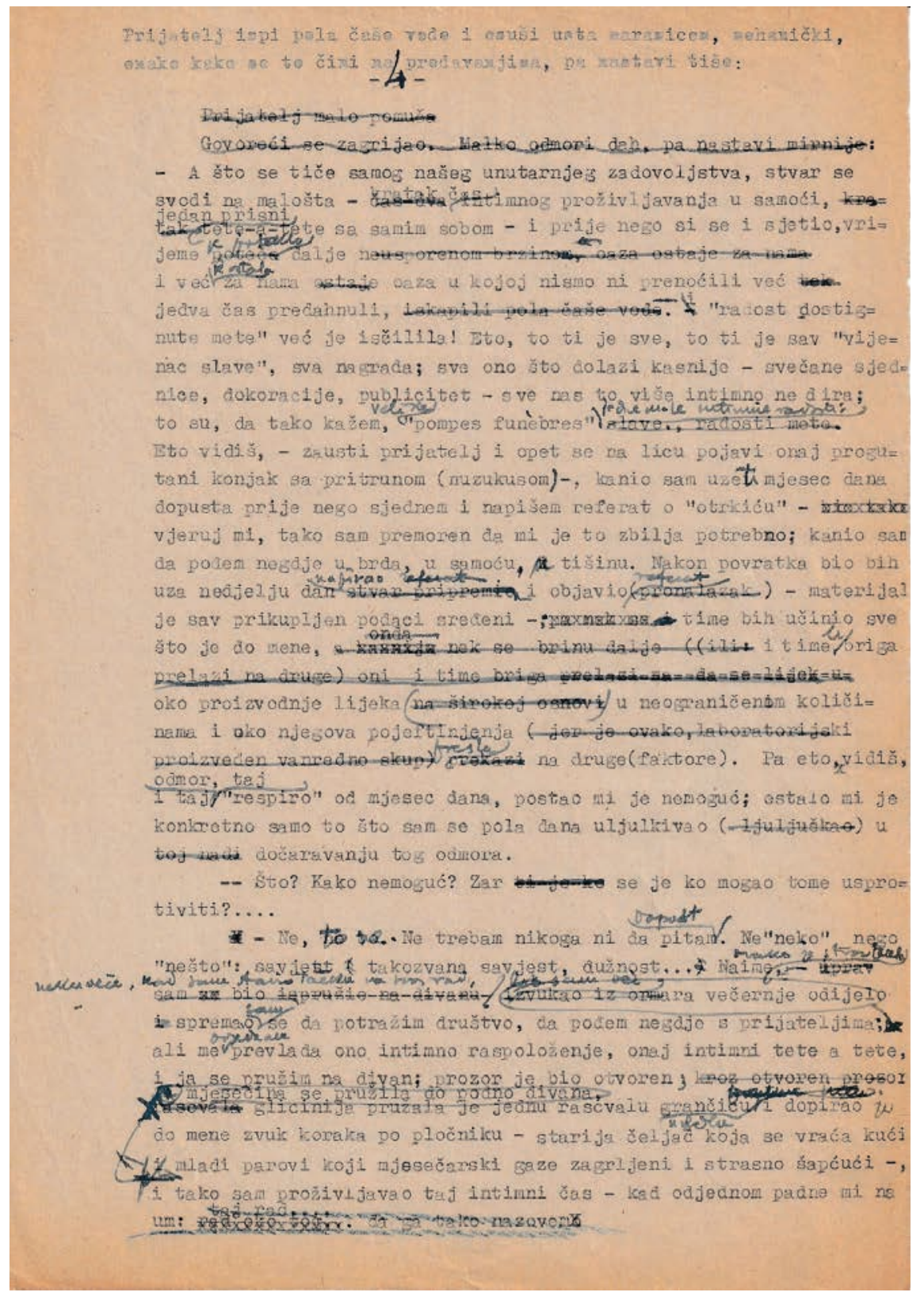

\section{Sl. 4. Čovječanstvo}

povijetkama Čovječanstvo i Dva prijatelja likovi su dvojica intelektualaca od kojih je jedan ljekar, a drugi književnik. Vidna je Desničina namjera da se analizirani problem postavi između polova „razuma i osjećajnosti“, kako bi dijametralne vizure ostvarile umjetnički dinamičnu interpretaciju. Demistifikujući naučni proces i svoje životno otkriće, liječnik X. dovodi pod sumnju altruizam kao stvarnu pobudu bilo kog pronalazačkog napora. On strogo promatra pitanje ljubavi za Čovječanstvo, odnosno za Čovjeka, i zaključuje da se samo 
prema konkretnom, prisutnom pojedincu može imati autentična ljudska empatija, dok je human odnos prema kolektivu stvar najobičnije dužnosti. Svojoj profesionalnoj savjesnosti, kojoj je podredio vlastita radna prava i žrtvovao lični komfor, liječnik oduzima etičku uzvišenost i svodi je na puko vršenje građanske službe:

Postupio sam nekako kao kuhar u menzi koji zna da na datu količinu juhe mora da saspe datu količinu soli; on tačno izvaga i uspe, i pouzdano zna da uprav toliko treba i da je stvar u redu, ali on nije okusio juhu, nije mu njegovo nepce kazalo da je dovoljno zasoljena. Ako hoću da budem iskren, moram priznati da smatram da prema „čovječanstvu“ niko ništa ne osjeća, da se prema čovječanstvu i ne može nešto osjećati; svih mori samo misao, spekulacija o čovječanstvu. I u tome je, vidiš, veliki minus te riječi „čovječanstvo“, veliki minus svih apstrakcija uopće.

Upravo poput nekih likova Dostojevskog ili Mana, Desničin junak izlaže svoju ideju neumoljivom materijalističkom logikom, ostavljajući nemoćnom sabesjedniku ulogu pasivnog slušaoca. Sagovornikovo neslaganje diskretno je naznačeno, ali je njegov uticaj na liječnikovo mišljenje potpuno izostao. Liječnikova teorija i njegova uvjerljiva retorika na isti način mogu djelovati na čitaoca. Ipak, pisac je u dva navrata svog junaka umjetnički suptilno obilježio znamenjem prirođene sumnjičavosti prema svemu što predstavlja izraz ljudskog vitalizma. Insistiranje na poređenju liječnikovih ekspresija sa reakcijama na gutljaje konjaka u kojima se prepoznaje nota neočekivanog, sumnjivog ukusa, upućuje na njegovo imanentno nepovjerenje, na suspektnost prema svemu što čovjek čini i stvara, bilo da je usmjereno ka dobru drugog, bilo ka vlastitom zadovoljstvu. Desničina pripovijedačka zainteresovanost za naoko nevažne detalje u kojima se otkriva neočekivana psihološka motivacija dobija u pripovijeci Čovječanstvo jedno od svojih uzoritih ispoljenja. ${ }^{21}$

Pripovijetka Dva prijatelja je u određenom smislu varijacija Čovječanstva - ponovo su glavni likovi liječnik i književnik, s tim da je fokus pomjeren sa filozofske ka socijalnoj i psihološkoj ravni. Prikazujući dvojicu ispisnika različitog društvenog statusa, Desnica otvara prostor za osobenu narativnu studiju o nemogućnosti komunikacije suprotstavljenih socijalnih i psiholoških tipova. U istrajnom naporu da od prijatelja dobije „stručnu pomoć" za jedan literarni rad, književnik Ivan svoje ne sasvim razumljive zahtjeve iznosi sve zbunjenijem sagovorniku. Njegova upornost da od liječnika dozna naziv bilo kakve bolesti „komičnog efekta“, pomoću koje bi okarakterisao junaka svoje nove pripovijetke, simbolički se završava praznom rubrikom dijagnoze "na tabli okačenoj podno postelje“ Ivanovog bolesničkog kreveta. Knjiga koju Ivan poklanja prijatelju i sama nosi obilježja poetike ovakvih Desničinih - ozbiljno-smiješnih novela - koja bi se mogla iskazati liječnikovim utiskom o Ivanovoj prozi:

$\overline{21}$ „Sakrivene (reče) i naoko nevažne, a kod malo produbljenijeg pogleda duboko značajne pojedinosti u odnosima između čovjeka i čovjeka. Mislim da otkrivanje i iznošenje toga i jest jedan od glavnih zadataka pisca. (Ovde Desnica malo zastade i onda ponovi kao da podvlači). Da to otkrije i učini bjelodanim što širem krugu ljudi." J. RaDULović (prir.), Djelo nastaje dalje od pisaćeg stola, 85-86. (Mlada kultura (Beograd), 29. 9. 1955.) 
A još ga više začudi to što je iz knjige, sve kroz šaljivi ton i smiješne anegdote, izbijala i hvatala čovjeka oko srca neka rasplinuta tuga za koju nije znao u čemu zapravo leži i iz čega izbija: komični ljudi, komične situacije, nevažni događaji, šaljiv ton, ležerne, često čak i neozbiljne šale, kalamburi i obrati riječi - a sve skupa tužno, tužno do suza.

Dva prijatelja, zajedno sa pripovijetkom Svejednako, oblikuju Desničin prepoznatljivi sumorni hronotop bolničkih soba i skučenih kancelarija, u kojima se sva čovjekova uzvišena nastojanja nemilosrdno poništavaju, a njegov život svodi na klaustrofobičnu, bilo bolesničku ili činovničku egzistenciju. Tom modernom književnom mitu čovjeka kao biološkog stroja i njegovog ropskog života u državnoj mašineriji Desnica je dao svoj umjetnički doprinos, pronalazeći u njemu izvjesnu tragikomičnu nijansu.

Tako pripovijetka Zasluženi odmor takođe osvjetljava jednu stranu čovjekove egzistencije u stanju fukoovski shvaćene „dobrovoljne podjarmljenosti“. Poreski kontrolor Ambroz Levak, preko svake mjere revnosni djelatnik u svojoj radnoj službi, na dan odlaska u penziju spoznaje čitav besmisao neprestanog odricanja, „bijedu čovjeka uopće, i svu pustoš utaman straćena života, uzaludnost žrtve, ništavnost svega ljudskog“. Levakova isključenost iz života i „dragovoljna“ predanost dužnosti na kraju traže utočište od oduzetog smisla postojanja i pronalaze ga u njegovanju „opće boli“, kao novom objektu apsolutne posvećenosti. Uznoseći ga tako do simbola čitave jedne ljudske klase, Desnica je u Zasluženom odmoru podvukao tamniju nijansu svog shvatanja apsurda čovjekove svojevoljne pokornosti, kao novovjekovnoj metafori njegove prigrljene neslobode.

Pripovijetke Uplakana ženica i Posjeta pjesniku takođe pripadaju vrsti piščevog visoko intelektualizovanog proznog izraza. Prva od njih još jedno je od Desničinih narativnih sučeljavanja sa literarno izazovnim pravnim aporijama. Ispisana u formi monologa, Uplakana ženica problematizuje krivicu čovjeka koji je, zloupotrebljavajući vlastiti položaj, iskoristio priliku da zavede ženu nasilnika o čijem prestupu ne zna ništa i tako nesvjesno „kaznio“ njegov zločin „dostojan“ smrtne kazne. Zatečena u stanju izvjesne nedorečenosti, pripovijetka može čitaoca staviti pred dilemu da li je u pitanju dovršen ili nedovršen tekst. Budući da retorički epilog svojim efektom upadljivo korespondira sa prologom in medias res, vjerovatnijom se može smatrati prva pretpostavka. U tom slučaju Desničina pripovijedačka virtuoznost ukazuje se ne samo u savladavanju obrazaca tradicionalne novelistike, već i suverenom kretanju kroz širok opseg formalnih mogućnosti žanra.

Mada očigledno ne sasvim dovršena, Posjeta pjesniku umnogome je reprezentativan primjer Desničine kratke novele: organizovana je kao razgovor dvojice prijatelja, sa dužim esejističkim pasažima i intelektualnim (samo)propitivanjem. Ovog puta tema je iz domena poetike, a problem sukob dvije generacije i dvije poetičke paradigme. Ojađeni pjesnik, kako je u jednoj od varijanti naslova imenovan, ne prikriva nezadovoljstvo razbarušenom asocijativnošću tek stasalog pjesničkog naraštaja. Njegova uvjerljiva i u jednoj mjeri duhovita interpretacija umjetničke prakse koju ne odobrava nailazi na čitaočevu saglasnost sve do trenutka dok kao motivacija na vidjelo ne izađe otpor pjesnikovog nećaka - pripadnika nove generacije - prema njegovim uzdržanim, „klasično“ pisanim stihovima. Slično nekim drugim srodnim pripovijetkama, Posjeta pjesniku ilustruje Desničin istančan senzibilitet za 


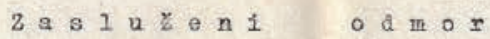

Kad je jeanog jutra poreski kontrolor Ambroz levak došao u ured $i$ doznao da je pensioniran, ostao je straǔno iznenacen. Covjek čeka pensiju cijeloga vijeka, pa ipak, eto, kad god ona došla, uvijek iznenadi - uprav keo $i$ smrt.

Što aad? - zepita ae levak poöto je sjeo za svoj sto. Nikad ranije nije razmišljao kako će to biti kad ode u pensiju 1 jto ce ted raditi. Pre= de letimirno u misli sve narine na koje se može upotrebiti vrijeme - ili bar sve narine dostupne njegovoj fantaziji - i misao mu se ni na jednone ne zaustavi! Pri pomisli na to stanje koje ce uskoro de nastupi, pred nje= govin je očima zjapile pr znina 1 billa neugodnim hladom.

Levak je bio krajnje uredan $i$ suv čovjek. U kancelariju je dolazio najprvi, nikad nije èitao novine u uredu niti je zviždukao gledajuei kroz prozor, sa rukama ga ledima. Za svih tridesetpet godina službe nije ni jeck= nom iskoristio godi.̌nji odmor. Nije imao ni rodbine ni prisnijih prijatelj= skih veza; svoju samocu nije dijelio cak ni s kuretom ili kuénom mačkom. " Ne razumijen isako se mogu voljeti šivotinje " - znao b1 reć1. -" Yoljeti životinje!" - To mu je zvučilo kao protuslovlje u izrazima. Sev se njegov ži vot svodio na malo sta, na šacicu suveži, na dvije-tri ostre ali bezizrazne i nezanimljive orte. Okoreli neženja bio je vječito mrzovoljast, mučaljiv, krto praskeve temperamenta. Nije se druzio ni s kolegama; čim bi izašli iz ureda, odvojili bi se: oni su se ne izlasku motali pred vratima 1réelrujući jeani aruge, a on bi se probio liroz njihova güvu $i$ uputio se hitrin kora= kom u gostionu u kojoj je gam rucavao. Hije tmao arugih navika ni pagija osin duönosti, 1 bile su mu neshvatljive pasije drugih. Jedan od kolega, filatelista, ponekad bi rasporedio po avome atolu nekoliko maraka i raz= gledao ih. Levak je mahso glavom nad njegovom slaboscu 1 govorio u sebi: " Ne razumijem kako se mogu kupiti marke!"

Ovo ga je sad iznebus̆ilo! B̂to da poüne? - Ukaza nu se perspaktiva dugih, sivih oana, bez rada, bez svrhe.... to jo sovu "zasluženim odmo= rom" !! Th, glupe fraze! Podilazila ga je srdrbe kad bi nu pala na um ta riječ; Jasnije nego ikad one mu je sad zvučala isprazro 1 lažno, kao izja= va saučěća na sprovodima.

Jutro mu se uëini beshrajno dugo. Jzimao je preda se sed fodon aad drugi proamet, pa in opet ostavijao. Wije mu se dalo. Opet mu zaburgije mi= sao: bto sad? Jcome, Čemu da posveti svoju brižjivost, svoje vrijeme? He što da usredsredi svoja nastojanja, svoju savjesnost?

Stade premetati po ladicems 1 sakupljati svoje lične stvarčice ko= jo će ponijeti kad ode. Pe prekide 1 to sjetivši se da mu ga to ostaje jor

\section{Sl. 5. Zasluženi odmor (konačna verzija)}

prepoznavanje komičnog u konfrontiranju opozitnih intelektualnih stavova, koji u podjednakoj mjeri polažu pravo na (ne)pravovaljanost.

Pripovijetka Noć u Skrocima oblikuje poznatu dihotomiju Desničine proze oličenu u opoziciji selo - grad. Za razliku od piščevih ranijih radova na tu temu, nije više riječ o fabularnom prikazivanju složenosti tog odnosa, već o naratorovim iskustvima i razmi- 
šljanjima povodom stereotipa vezanih za seoski ambijent. Obilje zdrave hrane ili seljakov neobični dnevni ritam, neke su od predrasuda koje pripovjedač u svojim monolozima razobličuje. Ipak, poseban doživljaj vremena i prostora na selu sada uzrokuje specifičnu percepciju gradske civilizacije, od savremene medicine do klasične književnosti, koja otkriva svoju drugačiju suštinu u sredini izvorne nepripadnosti. Čitanje Geteovog Vertera na selu, gdje provodi čitavu zimu, otvara pripovjedaču novu dimenziju kulture čiji je taj roman sublimni izdanak. $U$ tom recepcijskom obrtu narator zatvara krug svojih refleksija i dolazi do saznanja da ovještala mišljenja posjeduju svoje dublje antropološko utemeljenje. Na neki način, pripovijetka se može posmatrati kao esencija Desničinih narativnih analiza odnosa sela i grada, budući da jezgrovito, koliko i duhovito, izražava njegovo poetičko iskustvo:

Jednom su me opomenuli da nije patriotski prikazivati selo i život u njemu onakvim kakav jest ili, bar, onakvim kakvim ga je čovjek svojim očima vidio i na svojoj grbači iskusio. Pred ulazom u takvo selo trebalo bi, valjda, postaviti šatru koja bi iznajmljivala naočare od polaroidne materije, kao za trodimenzionalne filmove. Pri izlasku iz sela trebalo bi, naravno, naočare vratiti; jer ne bi bilo pravo da čovjek, za skromnu posudbenu cijenu, kasnije dovijeka gleda ružičasto čitav život. S druge strane, zamjera se Lazi Lazareviću što je opisivao selo idealizirano, onakvo kakvo ustvari ono nije. Ali ima i jedno srednje, koncilijantno rješenje: ako je selo koje si ti doživio doista onakvo kakvim ga ti opisuješ, zašto si uzeo da prikazuješ baš to i takvo selo! Izaberi neko drukčije i bolje. No što se može kad ti dobro poznaš baš ono i onakvo selo, i kad grešno misliš da je ono odnekud značajno i zanimljivo, i da ga treba opisati, upravo zato i po tome što je takvo!

Kako se vidi, Desnica je u svojim kratkim novelama bio skloniji refleksiji, nasuprot pretežnoj narativnosti njegovih dužih pripovijedaka. Nedovršena proza Onkel, razvijena u osnovnoj zamisli do određene misaone cjelovitosti, bavi se ljubavnim zanosom kao predmetom fenomenološke analize. Desničino relativno rjeđe umjetničko zanimanje za erotske motive (izuzetak su pripovijetke Od jutra do mraka i Šarasta kutijica) postojalo je, dakle, i u formi refleksivne proze. Sa druge strane, njegova naklonost anegdotskom koje u sebi nosi dublje antropološke implikacije odlikuje priču Aperitiv. Po sebi više slika nego pripovijest, ta prozna minijatura, zasnovana na trivijalnom nesporazumu oca i sina za trpezarijskim stolom, sadrži kolektivni portret nekoliko novih „olupina na suncu“ - što je prikladna odrednica većini likova koje pisac ovim pripovijetkama pridružuje svojoj već bogatoj galeriji.

Desničine „Novele u radu“ na nekoliko nivoa predstavljaju značajan prilog piščevom proznom opusu, čija će se visoka vrijednost njihovim publikovanjem dodatno potvrditi. 


\section{ShORT FICTION - Vladan DesniCA's unfinished THIRD BOOK OF NOVELLAS AND OTHER SIMILAR TEXTS FROM HIS LITERARY ESTATE}

Summary: Novellas comprise the majority of Vladan Desnica's literary estate. The thirty seven manuscripts and dactylograms discovered after his demise, of varying sizes and degrees of completeness, and only one of which was ever published in a periodical in his lifetime, provide insight into Desnica's storytelling process and change our understanding of that aspect of his literary work. The surviving list, which contains eighteen titles, shows that Desnica had planned to publish a third book of novellas (alternatively titled Short fiction). It is also evident that Desnica abandoned the original concept and was obviously working on his stories with the intent of publishing them in a different conceptual form. In accordance with their degree of artistic completeness, twelve texts have been selected with the aim of publishing a critical edition in the near future. The titles in question are: Nobelovac (The Nobel Prize Winner), Uplakana ženica (The Weeping Little Woman), Čovečanstvo (Humankind), Tetka Melanija (The Aunt Melanija), Aperitiv (The Aperitif), Dva prijatelja (Two friends), Istina o Adalbertu (The Truth About Adalbert), Noć u Skrocima (A Night in Skroci), Onkel, Posjeta pjesniku (A Visit to A Poet), Svejednako (All the Same) and Zasluženi odmor ( $A$ Well-Deserved Break). This paper provides a textological analysis of the aforementioned selection and discusses its position in the context of Desnica's body of work as writer of short fiction. It also provides an analysis of those aspects of the poetics of these novellas which shift our understanding of Desnica's narrative techniques. Just as they change our understanding of Vladan Desnica as an artist, these texts shape our perception of his place within the literary and historical context he worked in.

Key words: short story, novella, short novella, manuscript, literary estate

\section{$\cos$}

\section{Izvori}

Vladan DesnicA, Fratar sa zelenom bradom, Zagreb 1959.

Vladan Desnica, Hotimično iskustvo I i II (prir. Dušan Marinković), Zagreb 2005. - 2006.

Vladan Desnica, Olupine na suncu, Zagreb 1952.

Vladan Desnica, Proljeća Ivana Galeba, Beograd 1990.

Vladan Desnica, Proljeće u Badrovcu, Beograd 1955.

Vladan Desnica, Pronalazak Athanatika, Zagreb 2006.

Vladan Desnica, Tu, odmah pored nas, Novi Sad 1956.

Ilustrirani vjesnik, br. 184, 5. 3. 1949.

Letopis Matice srpske, 131/1955., knj. 376, br. 7-8.

Letopis Matice srpske, 148/1972., knj. 409, br. 5.

Magazin Sjeverne Dalmacije, 1935.

Novela film, 6/1954., br. 38. 


\section{Literatura}

Silvije Strahimir KranjčEvić, Izabrane pjesme, Beograd 1929.

Dušan Marinković, „Nove spoznaje o Vladanu Desnici“, Desničini susreti 2005.-2008. Zbornik radova (ur. Drago Roksandić i Ivana Cvijović Javorina), Zagreb 2010., 241-254.

Jovan Radulović (prir.), Djelo nastaje dalje od pisaćeg stola, Beograd 2005.

Drago RoKsandić, „Kud koje žure brzi kraci / a vode svi u bespuće'“: Vladan Desnica u Splitu od 1935. do 1941. godine", Split i Vladan Desnica 1918. - 1945.: Umjetničko stvaralaštvo između kulture i politike. Zbornik radova sa znanstvenog skupa Desničini susreti 2015. (ur. Drago Roksandić i Ivana Cvijović Javorina), Zagreb 2016., 415-458. 
